Assiut Provincial Laboratory,

Animal Health Research Institute.

\title{
DETECTION AND IDENTIFICATION OF SALMONELLA ISOLATED FROM CHICKENS BY POLYMERASE CHAIN REACTION (PCR)
}

(With 2 Tables and 9 Figures)

By

FАTMA М. МОНАMED; М.A. МОНАMED*; NABAWIA M. SHATA and A.M.A. MANAA

* Dept. Poultry Diseases, Fac. of Vet. Med., Assiut University, Assiut, Egypt (Received at 4/8/2009)

الكشف والتعرف على معزولات السالمونيلا من الاجاج بإستخدام إختبار البلمرة البيأ

فاطمة مختار محدد ، مؤمن عبل العظيم مدمد ، نبوية محمود شداتة أحمد معدوح مناع علد العظم معل

يعتبر ميكروب السالمونيلا من الميكروبات الخطيرة لأنة أحد مسببات التسمم الغذائى للانسان

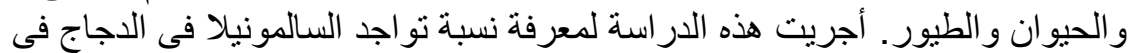
محافظة أسيوط، وكذلك الأختلافات الجينية بين المعزو لات التئ المختلفة باستخدام اختبار البلمرة.

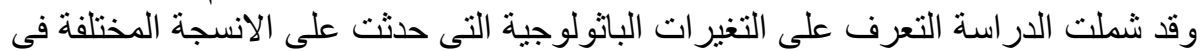

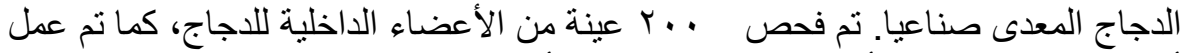

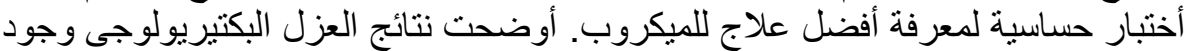

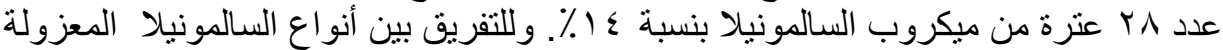

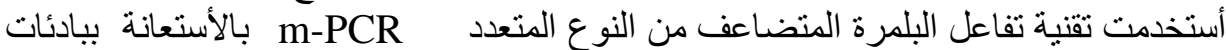

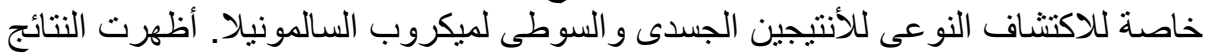

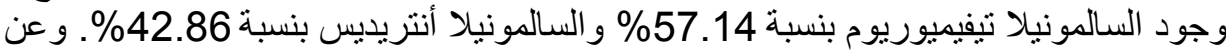

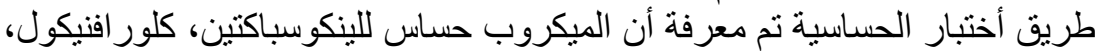

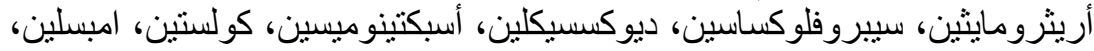

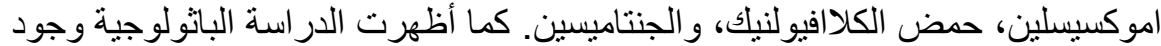

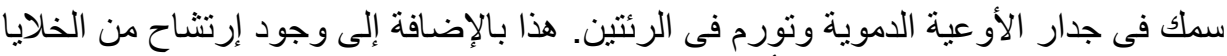

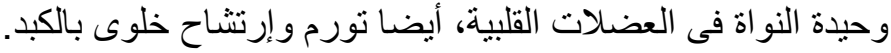

\section{SUMMARY}

The occurrence and identification of Salmonella spp. using a multiplex PCR (m-PCR) in chickens, as well as histopathological changes in 
experimentally infected chickens and antibiotic sensitivity test were studied. 200 samples (intestine, liver) were collected from freshly dead bird for bacteriological examination. 28 Salmonella isolates were found in chicken samples with overall percentage $14 \%$, by conventional culturing and biochemical reactions. Seven representing isolates were confirmed by a multiplex-PCR (m-PCR) using the three primers pair (ST11-F, ST15-R), (S1-F, S4-R) and Fli15-F, Fli15-R for identification of the most frequent Salmonella enterica serovars. Our results revealed that isolation rate of serovar Enteritidis was $57.14 \%$ (16/28) and $42.86 \%$ $(12 / 28)$ were identified as serovar Typhimurium. Histopathologically of the experimentally infected chicken showed thickening of the alveolar wall, blood vessel wall and edema in the lung. Moreover, mononuclear cell infiltration in cardiac muscles and hepatic edema with heterophil cells infiltration in infected liver was also seen. The current study demonstrated that all of 28 Salmonella strains were susceptible to lincospectin, chloramphenicol, erythromycin, ciprofloxacin, doxycyclin, spectinomycin, colistin but were resistant to ampicillin, amoxicillin/clavulanic acid and gentamycin.

Key words: Salmonella, Chickens, Multiplex-PCR, Antibiotic Resistance.

\section{INTRODUCTION}

Salmonella enterica is one of the most important leading pathogens of food-borne illness throughout the world that pose a significant health hazard to human. Infected poultry are the most frequently incriminated reservoirs of Salmonellae that can be transmitted through the food to human (Clavijo et al., 2006; Humphrey, 2006). Food-borne diseases caused by Salmonella serotypes occur at high frequency in industrialized nations and developing countries and represent an important public health problem worldwide (White et al., 2001; Lampel et al., 2000). Salmonella enterica subsp. enterica serovar Typhimurium are the major dominating serotypes of Salmonella in poultry and poultry product (Young, et al., 2003; Gürakan et al., 2008). Salmonella spp. is one of the most important pathogens responsible for gastrointestinal infections in human, poultry and its derivatives being one of the best known sources of contamination. An increase of strains showing individual and multiple resistance against different antibiotics have been found from isolates from pigs, poultry, and cattle in recent years (Esaki et al., 2004). Standard culture methods for detecting Salmonella spp. in poultry include non-selective pre-enrichment 
followed by selective pre-enrichment followed by selective and differential agars (Whyte et al., 2002). These methods take approximately 4-7 days (Harvey and Price, 1979; Perales and Audicana, 1989). Since Salmonella is closely related to both public and animal health, more rapid and sensitive methods for the identification of this bacterium are required (Schrank et al., 2001). Several alternative, faster methods for the detection of Salmonella have been developed, the use of the polymerase chain reaction (PCR) being one of the most promising approaches (Candrian, 1995; Scheu et al., 1998). Rapid identification methods are based on genomic amplification techniques using distinct target DNA sequences determined by PCR. Recently, specific identification of S.enterica serovars Typhi and Paratyphi A by multiplex PCR, which detects $r f b E, r f b S$, viaB, and fliC genes, has been reported, and this method correctly identify $S$. enterica serovars Typhi and Paratyphi A and differentiate these from other Salmonella serovars that have similar antigenic structures (Hirose et al., 2002; Young et al., 2003).

\section{The aim of this study:}

1- Determination of prevalence rate of Salmonella infection among broiler chickens in Assiut.

2- Using a multiplex PCR method for Salmonella enterica serovars identification.

3- Histopathological changes in intestine and liver post infection with Salmonella.

4- Antibiotic sensitivity test to select the best treatment of Salmonella infections in chickens.

\section{MATERIALS and METHODS}

\section{Sample collections:}

Two hundreds samples from internal organs (intestine and liver) were collected from diseased broiler chickens of different farms that were necropsied at Department of Poultry Diseases, Faculty of Vet. Med., Assiut University from different localities in Assiut province. The selected birds showed diarrhea, vent pasting and stunting in forty five days chickens. The post mortem examination of all the cases was performed for the all dead birds. At necropsy, gross lesions were recorded carefully, and representative tissue samples from clinically diseased birds and experimental infected birds containing lesions were fixed in $10 \%$ neutral buffered formalin for histopathological studies. 


\section{Culture procedure:}

Samples were aseptically cultured into selenite F broth (Oxoid) and incubate at $41^{\circ} \mathrm{C}$ for $18-24$ hours. Subsequently, a loop full of each broth was streaked on surface of MacConky agar, Salmonella Shigella agar (S.S. agar) and Xylose Lysine Desoxycholate agar (X.L.D. agar) for further incubation at $37^{\circ} \mathrm{C}$ for $24 \mathrm{~h}$ (FDA, 1992).

\section{Bacteriological method for Salmonella identification:}

Salmonella-typical colonies on the plates were confirmed with standard biochemical tests and procedures for Salmonella spp. (Rotger and Casadesús, 1999). Presumptive Salmonella colonies were kept at $70^{\circ} \mathrm{C}$ brain heart infusion broth (Difco) with the addition of $20 \%(\mathrm{v} / \mathrm{v}$ ) glycerol. An aliquot of this storage solution was taken and incubated in 5 $\mathrm{ml}$ phosphate-buffered peptone water for $24 \mathrm{~h}$ at $37^{\circ} \mathrm{C}$ prior to multiplex PCR for further confirmation.

\section{Salmonella Molecular identification}

\section{Genomic DNA extraction}

The liquid cultures were centrifuged at $8,700 \times \mathrm{g}$ for $15 \mathrm{~min}$, and the cell pellets were re-suspended in $1 \mathrm{ml}$ of sterile water. The resuspended cells were re-centrifuged at $12,500 \mathrm{x} g$ for $15 \mathrm{~min}$. The pelleted cells were then used for DNA extraction as followed by manufacturer instructions for QIAamp DNA miniprep kit and the concentration was determined using ultraviolet spectrophotometer at $A_{260}$.

\section{Subtyping of Salmonella serotypes using multiplex-PCR (m-PCR):}

To develop a multiplex-PCR for Salmonella serotypes identification, three pairs of primers were designed from published primer sequences as shown in (Table 1). The multiplex PCR reaction contained $5 \mu \mathrm{L}$ of template DNA, $0.4 \mu \mathrm{M}$ of each primer, $100 \mu \mathrm{M}$ of each deoxynucleotide triphosphate, $1.25 \mathrm{mM}$ of MgCl2 $(25 \mathrm{mM}), 2.5 \mathrm{U}$ of Taq Polymerase, $5 \mu \mathrm{L}$ of 10X PCR Buffer (Promega Corp., MI, USA), and water to bring the final reaction volume to $50 \mu \mathrm{L}$.

PCR was performed in a Techne Cyclogene PCR System thermocycler. The temperature program started with a PCR amplification was as follows: one initial denaturation cycle at $95{ }^{\circ} \mathrm{C}$ for 5 min, followed by 30 cycles of $95{ }^{\circ} \mathrm{C}$ for $40 \mathrm{~s}, 58{ }^{\circ} \mathrm{C}$ for $20 \mathrm{~s}$ and $72{ }^{\circ} \mathrm{C}$ for $20 \mathrm{~s}$, and one final extension cycle of $72{ }^{\circ} \mathrm{C}$ for $7 \mathrm{~min}$. Finally, the samples were cooled to $4^{\circ} \mathrm{C}$. Fragments were separated in $1 \%$ agarose gel by unidirectional electrophoresis and visualized by staining with ethidium bromide. Fragment sizes were determined by comparison with a $1 \mathrm{~KB}$ plus DNA ladder (Invitrogen). 


\section{Histopathology:}

The tissues were collected from experimentally infected birds then subjected to fixation in neutral buffered formalin, trimming, washing and dehydration in ascending grades of ethanol, clearing in methylbenzoate and embedding in paraffin. $5 \mu \mathrm{m}$ thick sections were cut, stained with hematoxylin and eosin (Habib-ur-Rahman, et al, 2003). Sections were examined in the Department of Pathology, Faculty of Veterinary Medicine, Assiut University.

\section{Antibiotic sensitivity test:}

Salmonella-typical colonies on the plates were culture into brain heart infusion broth over night at $37^{\circ} \mathrm{C}$ and culture fluently over the entire surface of nutrient agar (Difco) with sterile cotton swab. Commercial antibiotic disks containing single concentrations of each antibiotic were then placed on to the inoculated plate surface. The zone of growth inhibition around each disk after over night incubation at $37^{\circ} \mathrm{C}$, were measured in millimeters. The zone diameter was interpreted using a zone size interpretation chart (Lorian, 1996). The antibiotics and their concentration were as follow. lincospectin, chloramphenicol $30 \mu \mathrm{g}$, erythromycin $10 \mu \mathrm{g}$, ciprofloxacin $5 \mu \mathrm{g}$, doxycyclin $30 \mu \mathrm{g}$, spectinomycin $10 \mu \mathrm{g}$, colistin $25 \mu \mathrm{g}$, enrofloxacin $5 \mu \mathrm{g}$, ampicillin $10 \mu \mathrm{g}$, amoxicillin/ calvulanic acid $10 \mu \mathrm{g}$, and gentamycin $10 \mu \mathrm{g}$ (Quinn et al., 1994).

\section{RESULTS}

\section{Isolation of Salmonella from the examined samples:}

The isolation trials of Salmonella from collected samples yielded overall isolation rate $14 \%(28 / 200)$ of the examined birds. Using biochemical reactions the highest isolation rate of the 28 Salmonella isolates, $16(57.14 \%)$ were identified as serovar Enteritidis, while 12 $(42.86 \%)$ were identified as serovar Typhimurium. Of the above mentioned 28 isolates, 7 representing ones were used to confirm identification using multiplex PCR. Of these 7 isolates 4 were identified as serovar Enteritidis, while 3 were identified as serovar Typhimurium (Fig. 1).

\section{Specificity of the multiplex polymerase chain reaction:}

For multiplex PCR, 3 primer pairs were used, (ST11-F, ST15-R), (S1-F, S4-R) and (Fli15-F, Fli15-R). The results revealed that no amplification could be observed among non-Salmonella strains as a 
negative control, but a specific amplification (429bp) could be detected in all Salmonella strains for the genus Salmonella, whereas (Fli15-F, Fli15-R) primer pair could amplify a 650bp fragment among the tested strains of $S$. Typhimurium only. However, (S1-F, S4-R) primer pair could amplify a $250 \mathrm{bp}$ fragment, examined strains of $S$. Enteritidis (Table2).

\section{Pathology:}

Gross examination of the infected birds showed marked lesions in many organs. The lung appeared severely congested (Fig.2). The intestinal and cecal walls were congested (Fig.3). Liver was enlarged with dark red discoloration and friable consistency (Fig.4). Hemorrhages were also demonstrated at the junction between proventriculus and gizzard (Fig.5).

The aim of histopathological examination is detect the pathological action of the Salmonalla microorganisms on different tissues and organs. Our results revealed severes acute systemic lesions in almost all body parts. H\&E stained sections of intestine exhibited mucosal epithelial cell necrosis, the submucosal blood vessels appeared dilated, engorged with blood with edema in their walls. Extravascular red blood cells (RBCS) could be seen mixed with infiltration of a granular mononuclear cells and heterophils in the submucosa. Hepatic lesions were characterized by multifocal necrosis of hepatocytes and vascular congestion (Figs $6 \& 7$ ). The lung revealed thickening of the alveolar wall due to massive infiltration with heterophils and lymphocytes. Degenerated alveolar wall were fused forming emphysemas (Fig.8). Cardiac muscles demonstrated heterophilic and mononuclear cell infiltration (Fig.9).

\section{Antibiotic sensitivity test:}

All 28 Salmonella isolates were susceptible to the antimicrobial effect of lincospectin, chloraphenicol, erythromycin, ciprofloxacin, doxycyclin, spectinomycin, colistin, but they were resistant to ampicillin, amoxicillin/clavulanic acid and gentamycin. 
Table 1: Primers used in this study for multiplex-PCR identification of the most frequent Salmonella.

\begin{tabular}{|c|c|c|c|c|}
\hline Primer & $\begin{array}{c}\text { Length } \\
\text { (nucleotides) }\end{array}$ & Primer sequence & $\begin{array}{l}\text { Amplicon } \\
\text { Size (bp) }\end{array}$ & Reference \\
\hline ST11-F (1) & 24 & GCC AAC CAT TGC TAA ATT GGC GCA & \multirow[t]{2}{*}{429} & \multirow{2}{*}{$\begin{array}{l}\text { Aabo } \\
\text { et al..,1999 }\end{array}$} \\
\hline ST15-R (1) & 25 & GGT AGA AAT TCC CAG CGG GTA CTG G & & \\
\hline S1-F (2) & 20 & GCC GTA CAC GAG CTT ATA GA & \multirow[t]{2}{*}{250} & \multirow{2}{*}{$\begin{array}{c}\text { Soumet } \\
\text { et al.,1999 }\end{array}$} \\
\hline S4-R (2) & 20 & ACC TAC AGG GGC ACA ATA AC & & \\
\hline Fli15-F (3) & 22 & CGG TGT TGC CCA GGT TGG TAA T & \multirow[t]{2}{*}{620} & \multirow{2}{*}{\begin{tabular}{|l} 
Soumet \\
et al.,1999
\end{tabular}} \\
\hline Fli15-R (3) & 16 & ACT GGT A & & \\
\hline
\end{tabular}

(1) Salmonella sp., (2) S. entertidis, (3) S. typhimuriym

Table 2: Specificity of the multiplex PCR

\begin{tabular}{|c|c|c|c|c|}
\hline \multirow{2}{*}{ Strains } & \multirow{2}{*}{$\begin{array}{c}\text { Number of } \\
\text { strains }\end{array}$} & \multicolumn{3}{|c|}{$\begin{array}{c}\text { PCR-positive results by m-PCR with } \\
\text { amplified products of }\end{array}$} \\
\cline { 3 - 5 } & & $429 \mathrm{pb}$ & $620 \mathrm{pb}$ & $250 \mathrm{pb}$ \\
\hline$S$. Enteritidis & 3 & 3 & 0 & 3 \\
\hline $\begin{array}{c}S . \\
\text { Typhimurium }\end{array}$ & 4 & 4 & 4 & 0 \\
\hline
\end{tabular}

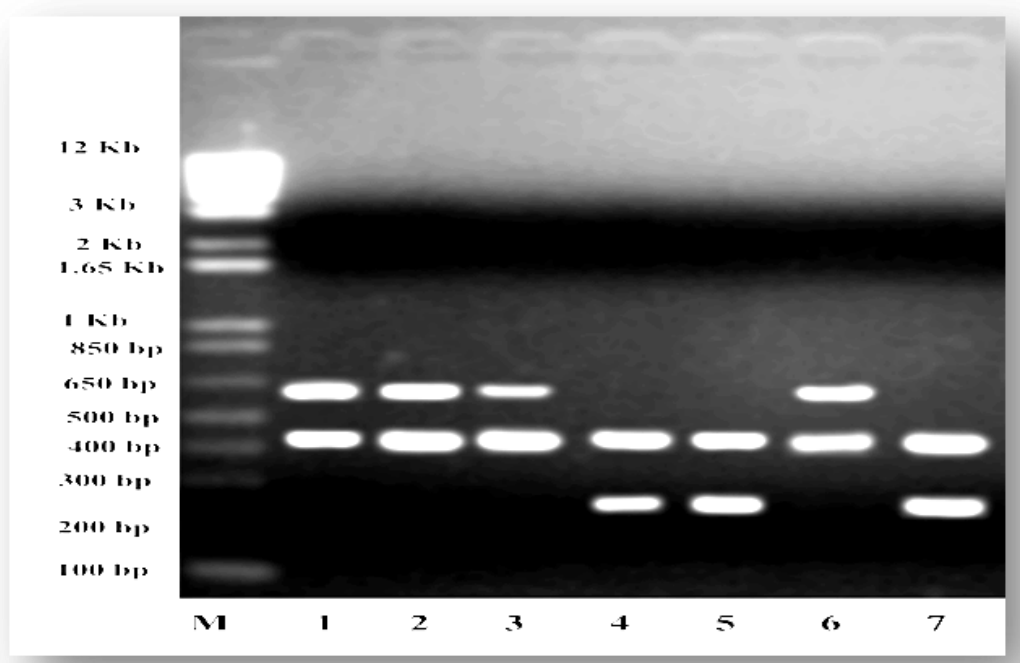

Fig. 1: Mutltiplex PCR amplification from various suspected Salmonella strains, $S$. Typhimurium lanes $(1,2,3,6)$ and $S$. Enteritidis lanes (4 and 5), M, 1KB plus DNA ladder (Invitrogen). 
Assiut Vet. Med. J. Vol. 55 No. 123 October 2009
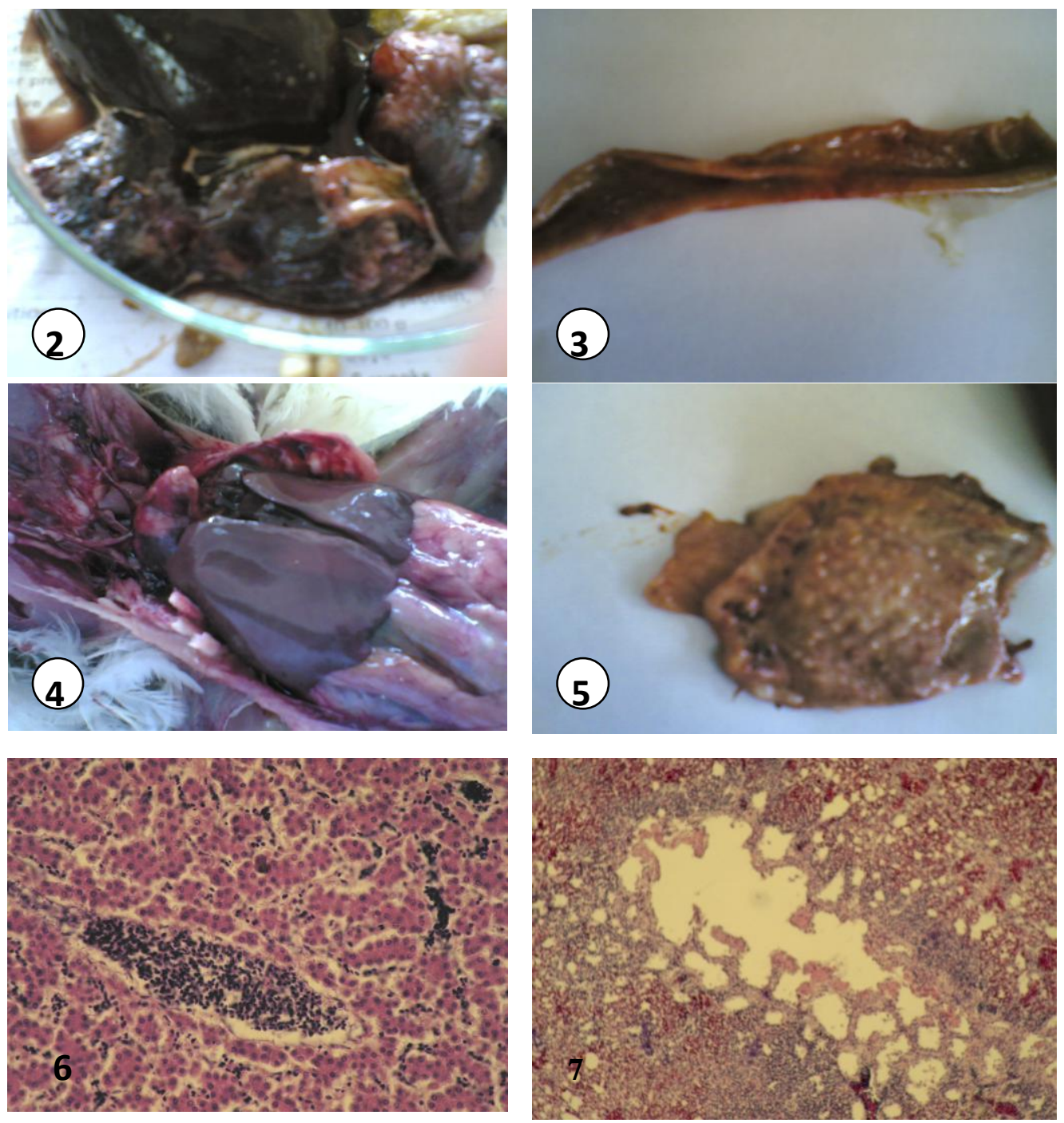


\section{LEGENDS}

Fig.2: Lungs of infected chickens showing different stages of pneumonia

Fig.3: Intestine of infected chickens showing focal necrotic intestinal lesions.

Fig.4: Liver and heart of infected chicken showing perihepatitis and pericarditis.

Fig.5: Hemorrhages in the junction between proventriculus and gizzard (arrow).

Fig.6: Liver of infected chicken showing congestion and oedema with heterophil cell infiltration.

Fig.7: Lung of infected chicken showing effusion and thickening of the degenerated alveolar wall due to massive heterophilic and mononuclear cell infiltration.

Fig.8: Lung of infected chicken showing septal and prevascular edema.

Fig.9: Cardiac muscles showing heterophilic and mononuclear cell infiltration.

\section{DISCUSSION}

Salmonella enterica are recognized as major food-borne pathogens in the world (Gatto et al., 2006). The predominant serotypes change over time and differ from one geographical area to another. All over the world, as well as in our country, the most often isolated serotype is $S$. Enteritidis (Gatto et al., 2006). In this study, the Salmonella detection rate was the highest (14\%) in chicken carcasses. These results are in general agreement with previous results that Salmonella in poultry products were generally low and ranged from $8 \%$ in Albania (Beli et al., 2001), 12\% in turkey (Ozbey and Ertas, 2006), 23-34\% in Belgium (Uyttendaele et al., 1998, 1999), 25\% in United Kingdom (Plummer et al., 1995), 26\% in Ireland (Duffy et al., 1999), $36 \%$ Malaysia (Rusul et al., 1996) to $43 \%$ in USA (Bokanyi et al., 1990). However, Antunes et al. (2003) mentioned that poultry samples are frequently contaminated with Salmonella (60\%) which belong to 10 different serotypes. The controversy in the results could be attributed to several factors such as differences in origin, time period and age of the diseased birds, sampling procedure, and differences in methodology 
applied to detect the pathogen (Bryan and Doyle, 1995; Uyttendaele et al., 1999).

The isolation trials adopted in the current study yielded that the overall isolation rate was $14 \%$ (28/200) of the examined birds. Using biochemical reactions, the serovar Enteritidis was identified from 16/28 with a percentage $57.14 \%$, while $42.86 \%(12 / 28)$ were identified as serovar Typhimurium. These results simulates recent reports from England and Spain that $S$. Enteritidis and $S$. Typhimurium are the most frequent serotype with incidences of $60 \%$ and $86 \%$, respectively (Gatto et al., 2006).

A Multiplex PCR-based assay (m-PCR) with three sets of primers was developed for the detection of the most common serotypes of $S$. enterica as $S$. Enteritidis and $S$. Typhimurium. This is a very rapid and simple molecular method for serotyping common Salmonella, the specific sequence could be detected in all Salmonella enterica serotypes. The time for serotyping is dramatically reduced to only $5 \mathrm{hrs}$. The method is basic and does not need specialized staff and a large collection of antisera. The assay may be applied in any clinical facility which has PCR and electrophoresis equipment.

In accordance with (Hirose, et al, 2002) a multplix PCR gave a positive result for all Salmonella strains yielding a specific fragment of $429 \mathrm{bp}$ at the genus level and an additional distinct $250 \mathrm{bp}$ amplified product of sefA, which allowed identification of $S$. Enteritidis, whereas an additional 620-bp amplified band was observed only in samples of $S$. Typhimurium serotype. Random amplified polymorphic DNA analysis with primer 3 is of potential use as a serotype-specific marker for $S$. Typhimurium, (Gürakan et al., 2008).

Our result reveals that all the 28 Salmonella isolates were susceptible to the antimicrobial effect of lincospectin, chloramphenicol, erythromycin, ciprofloxacin, doxycyclin, spectinomycin, colistin, but they were resistant to ampicillin, amoxicillin/clavulanic acid and gentamycin. This is partially consistent with results of (Zahraei Salehi et al., 2005) that 30 Salmonella strains were susceptible to the antimicrobial effect of cefotaxime, tylosin, colistin, ciprofloxacin, enrofloxacin, gentamycin, chloramphenicol, cephalotin and cefotaxime and resistent to trimethoprim, nalidixic acid, flumequine, tetracycline, neomycin, streptomycin, kanamycin and amikacin. However our results disagrees with the findings of Kristiansen et al. (2003) that Salmonella Typhimurium DT104, is resistant to streptomycin, chloramphenicol, amoxicillin, sulfonamides, and tetracyclines. 
Both gross and histopathological lesions of Salmonella infections in chicken are a great diagnostic tool besides bacteriological studies (Dhillon et al., 2001). The gross lesions demonstrated in the current study are in a general agreement with those of Talha et al. (2001), Habib-ur-Rahman et al. (2003) that include hepatic enlargement, hepatic and intestinal congestion besides dark red discoloration and fleshy consistency of the lung. Histopathologically, the present observations support previous studies (Talha et al., 2001; Habib-urRahman et al., 2003; Haider et al., 2004) and are expressed by congestion and hemorrhages with infiltration of mononuclear cells in the intestinal mucosa and submucosa, myocarditis, extravasated blood aggregates and edema. These pathological lesions could be attributed to the direct action of Salmonella which is a facultative intracellular microorganism (Buxton and Jean, 1963; Ruby et al., 2003).

\section{ACKNOWLEDGEMENTS}

The authors would like to acknowledge the head of the Department of Poultry Diseases for the facilities offered to complete this work. We also would like to thank all technical staff in the Laboratory of Poultry Diseases in the Department of Poultry Diseases, Faculty of Veterinary Medicine, Assiut University, Egypt.

\section{REFERENCES}

Aabo, S.; Rasmussen, O.F.; Rossen, L.; Sorensen, P.D. and Olsen, J.E. (1993): Salmonella identification by Polymerase Chain Reaction. Molecullar and Cellular Probes, 7:171-178.

Antunes, P.; Re'u, C.; Sousa, J.C.; Peixe, L. and Pestana, N. (2003): Incidence of Salmonella from poultry products and their susceptibility to antimicrobial agents. International Journal of Food Microbiology, 82: 97-103.

Beli, E.; Telo, A. and Duraku, E. (2001): Salmonella serotypes isolated from turkey in Albania. International Journal of Food Microbiology 63: 165-167.

Bokanyi, R.P.; Stephens, J.F. and Foster, D.N. (1990): Isolation and characterization of Salmonella from broiler carcasses or parts. Poultry Science, 69: 592-598. 
Bryan, F.L. and Doyle, P. (1995): Health risks and consequences of Salmonella and Campylobacter jejuni in raw poultry. Journal of food protection, 58: 326-344.

Buxton, A. and Jean, M.D. (1963): Studies on Immunity and Pathogenesis of Salmonellosis. Immunology, 6(6):530538.

Candrian, U. (1995): Polymerase chain reaction in food microbiology. Journal of Microbiology Methods, 23: 89-103.

Clavijo, R.I.; Cindy, L.; Gary, L.A.; Riley, L.W. and Sangwei, L. (2006): Identification of genes associated with survival of Salmonella enterica serovar Enteritidis in chicken egg albumen. Applied and Environmental, Microbiology, 72(2): 1055-1064.

Dhillon, A.S.; Shivaprasad, H.L.; Roy, P.; Alisantosaz, B.; Schaberg, D.; Bandli, D. and Johnson, S. (2001): Pathogenicity of environmental origin Salmonella in SPF eggs. Poultry Science 80: 1323-1328.

Duffy, G.; Cloak, O.M.; OSullivan, M.G.; Guillet, A.; Sheridan, J.J.; Blair, I.S. and McDowell, D.A. (1999): The incidence and antibiotic resistance profiles of Salmonella spp. on Irish retail meat products. Food Microbiology 16: 623-631.

Esaki, H.; Morioka, A.; Ishihara, K.; Kojima, A.; Shiroki, S.; Tamura, Y. and Takahashi, T. (2004): Antimicrobial susceptibility of Salmonella isolated from cattle, swine, and poultry (20012002): report from the Japanese Veterinary Antimicrobial Resistance Monitoring Program. J. Antimicrob. Chemother. 16: $1-5$.

Food and Drug Administration, (FDA), (1992): Salmonella. Bactiological Analytical Manual, Food and Drug Administration. AOAC International Arlington, VA, pp. 53-64.

Gatto AJ.; Peter, TM. and Green J. et al. (2006): Distribution of molecular subtypes within Salmonella enterica serotype Enterities phage type 4 and $S$. Typhimurium definitive phage type 104 in nine European countries, 2000-2004: results of an international multi-center study. Epidemiological infect; 25: $1-8$.

Gürakan, G.C.; Aksoy, C.; Ogle, Z.B. and Ören, N.G. (2008): Differentiation of Salmonella Typhimurium from Salmonella Enteritidis and other Salmonella serotypes using random amplified polymorphic DNA analysis Poultry Sciences, 87: 1068-1074. 
Habib-ur-Rahman S, Sirzanin; Hamayun, K.; Saleem, K.; Nazir, A. and Bhatti, WM. (2003): Incidence and gross pathology of Salmonellosis in chicken in hyderadad. J. Asso. And Vet. Advances. 2: 581: 584.

Haider, M.G.; Hossain, M.G.; Hossain, M.S.; Chowdhury, E.H.; Das, P.M. and Hossain, M.M. (2004): Isolation and characterization of Enterobacteria associated with health and disease in sonali chickens. Banganladesh Journal of Veterinary Medicine 2 (1): $15-21$.

Harvey, R.W. and Price, T.H. (1979): Principles of Salmonella isolation. Journal of Applied Bacteriology, 46: 27-56.

Hirose, K.; Itoh, K.; Nakajima, H.; Kurazono, T.; Yamaguchi, M.; Moriya, K.; Ezaki, T.; Kawamura, Y.; Tamura, K. and Watanabe, H. (2002): Selective amplification of tyv ( $r f b E)$, prt $(r f b S), v i a B$, and $f l i C$ genes by multiplex PCR for identification of Salmonella enterica serovars Typhi and Paratyphi A. J. Clin. Micobiol., 40: 633-636.

Humphrey, T.J. (2006): Public health aspects of Salmonella enterica in food production. In P. Mastroeni \& D. Maskell (Eds.), Salmonella infections: Clinical, Immunological and Molecular Aspects (pp. 89-115). Cambridge University Press.

Kristiansen, M.; Sandvang, D. and Rasmussen, T. (2003): In vivo Development of quinolone resistance in Salmonella enterica serotype Typhimurium DT 104. J. Clin. Microb. 41 (9), 4462-4464.

Lampel, K.A.; Orlandi, A.P. and Kornegay, L. (2000): Improved template preparation for PCR-based assay for detection of food-borne bacterial pathogens. Appl. Env. Microbial., 66: 4539-4542.

Lorian, V. (1996): Antibiotics in laboratory medicine. $4^{\text {th }}$ ed. Williams and Wilkins.

Ozbey, G. and Ertas, H.B. (2006): Salmonella spp. isolated from chicken samples and identification by polymerase chain reaction. Bulgarian Journal of veterinary Medicine, 9(1): 67-73.

Perales, I. and Audicana, A. (1989): Semisolid media for isolation of Salmonella from coastal waters. Applied and Environmental Microbiology, 29: 1281-1285.

Plummer, R.A.S.; Blissett, S.J. and Dodd, C.E.R. (1995): Contamination of retail chicken products sold in the UK. Journal of Food Protection 58: 843-846. 
Rotger, R. and Casadesús, J.B. (1999): The virulence plasmids of Salmonella. Internatl Microbiol 2: 177-184.

Ruby, R.; Uma, B.; Jie, M.; Subbiah, E.; Daniel, A.; Bautist, Richard, B.; Robert, A. and Wenxia, S. (2003): Clinical and diagnostic laboratory immunology, P. 670-679, Vol. 10, No.4.

Rusul, G.; Khair J.; Radu, S.; Cheah, C.T. and Yassin, R.MD. (1996): Prevalence of Salmonella in broilers at retail outlets, processing plants and farms in Malaysia. International Journal of food Microbiology 33: 183-194.

Scheu, P.M.; Berghof, K. and Stahl, U. (1998): Detection of pathogenic and spoilage micro-organisms in food with the polymerase chain reaction. Food Microbiology, 15: 13-31.

Schrank, I.S.; Mores, M.A.Z.; Costa, J.L.A.; Frazzon, A.P.G.; Soncini, R.; Schrank, A.; Vainstein, M.H. and Silva, S.C. (2001): Influence of enrichment media and application of a PCR based method to detect Salmonella in poultry industry products and clinical samples. Veterinary Microbiology, 82: 45-53.

Soumet, C.; Ermel, G.; Rose, N., Rose, V.; Drouin, P.; Salvat, G. and Colin, P. (1999): Evaluation of m-PCR assay for simultaneous identification of Salmonella spp., S. Entertidis, S.Typhimurium from environmental swabs of poultry houses. Lett. In Appl. Microbiol., 28:113-117

Talha, A.F.S.M.; Hossain, M.M.; Chowdhury, E.H.; Bari, A.S.M.; Islam, M.R. and Das, P.M. (2001): Poultry diseases occurring in Mymensingh district of Bangladesh. The Bangladesh veterinarian 18: 20-23.

Uyttendaele, M.R.; Debevere, J.M.; Lips, R.M. and Neyts, K.D. (1998): Prevalence of Salmonella in poultry carcasses and their products in Belgium. International Journal of Food Microbiology, 40: 1-8.

Uyttendaele, M.; De Troy, P. and Debevere, J. (1999): Incidence of Salmonella, Campylobacter jejuni, Campylobacter coli, and Listeria monocytogenes in poultry products for sale on the Belgian retail market. Journal of food protection 62: 735-740.

White, D.G.; Zhao, S.; Sudler, R.; Ayers, S.; Friedman, S.; Chen, S.; McDermott, P.F.; Wagner, D.D. and Meng, J. (2001): The isolation of antibiotic-resistant Salmonella from retail ground meats. N. engl. J Med., 345: 1147-1154. 
Whyte, P.; Gill, K.; Collins, J.D. and Gormley, E. (2002): The prevalence and PCR detection of Salmonella contamination in raw poultry. Veterinary Microbiology, 89: 53-60.

Young-Hee Lim; Kenji Hirose; Hidemasa Izumiya; Eiji Arakawa; Hideyuki Takahashi; Jun Terajima; Ken-ichiro Itoh; Kazumichi Tamura; Sung-II Kim and Haruo Watanabe (2003): Multiplex polymerase chain reaction assay for selective detection of Salmonella enterica serovar Typhimurium Jpn. J. Infect. Dis., 56: 151-155.

Zahraei Salehi, T.; Mahzounieh, M. and Saeedadeh, A. (2005): the isolation of antibiotic- resistance Salmonella from intestine and liver of poultry in Shiraz province of Iran. International Journal of poultry science 4(5): 320-322. 
Assiut Vet. Med. J. Vol. 55 No. 123 October 2009 
Assiut Vet. Med. J. Vol. 55 No. 123 October 2009
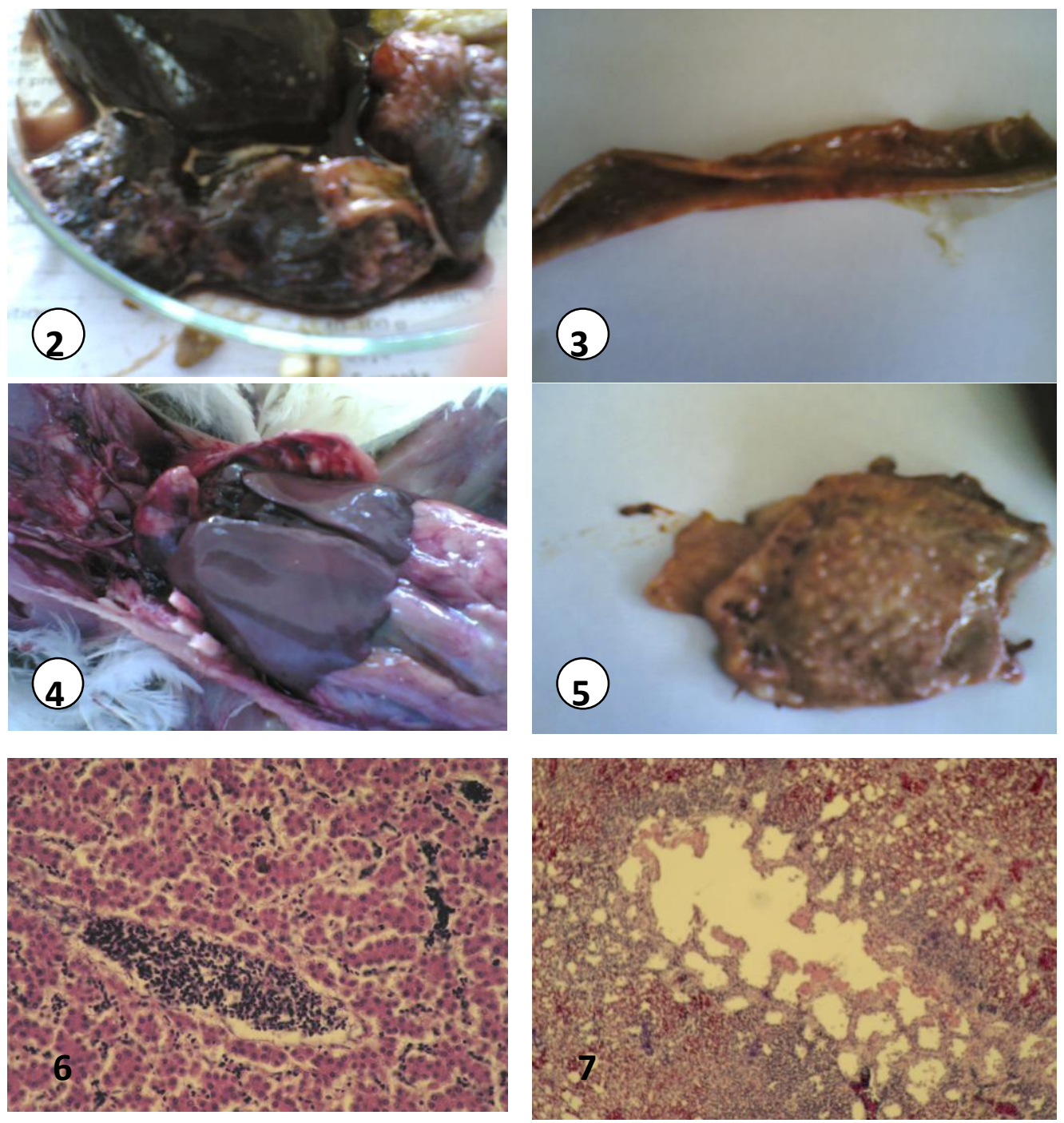
Assiut Vet. Med. J. Vol. 55 No. 123 October 2009 